\title{
Predicting pasture production under poplars using canopy closure images
}

\author{
A.J. WALL ${ }^{1}$, P.D. KEMP ${ }^{1}$ and A.D. MACKAY ${ }^{2}$ \\ ${ }^{1}$ Institute of Natural Resources, Massey University, PB 11222 Palmerston North \\ ${ }^{2}$ AgResearch, Grasslands Research Centre, PB 11008, Palmerston North \\ 1P.Kemp@massey.ac.nz
}

\begin{abstract}
Poplar trees serve a wide variety of purposes on New Zealand farms. Their high growth rate and ability to establish from poles make them a very suitable tree species for soil conservation plantings on erosion-prone hill pastures. The impact that such plantings have on understorey pasture production as the tree canopy develops in size was determined by measuring pasture dry matter (DM) production on three North Island sheep and beef hill farms. Poplars markedly reduced annual pasture production by up to $50 \%$ at high canopy closure. To maintain pasture production at $65-75 \%$ of uneroded open pasture, poplar canopy closure should not exceed $50 \%$. However, it must be emphasised that the loss in production through soil erosion (e.g. slips or earthflows) without poplars can be even greater, more permanent, and much more unpredictable.
\end{abstract}

Keywords: Populus, soil erosion, agroforestry, digital images, canopy closure, understorey pasture

\section{Introduction}

Poplars (Populus spp.) are a versatile species of tree widely used on New Zealand farms for a variety of purposes (McGregor et al. 1999; Wall et al. 1997; Wilkinson 1999). One of their primary uses, especially in North Island hill country, is soil conservation on unstable hill $\left(12^{\circ}-28^{\circ}\right)$ to steepland $\left(>28^{\circ}\right)$ topography where grazing is the primary land use (Hathaway 1986; Thompson \& Luckman 1993). Other reasons for planting poplars include providing shade and shelter, supplementary fodder for livestock, and wood or timber (Gregory 1995; Kemp et al. 2001; NZFRI 1995).

For rapid establishment and growth, poplars have narrower site requirements in terms of soil fertility, soil moisture and wind exposure than other commonly planted tree species such as Pinus radiata (Hathaway 1986; McKee 1976). However, on suitable sites, their fast initial growth and ability to establish from unrooted poles in the presence of stock is of considerable benefit where the aim is to obtain rapid erosion control while having minimal impact on normal pasture management (Miller et al. 1996; Wilkinson 1999). Where correctly planted and maintained for the type of soil erosion present, poplars can reduce soil erosion close to levels found on stable hillsides within 5 to 10 years of planting (Hicks 1992). Even after severe erosion events, such as Cyclone
Bola (1988) in the Gisborne region, field surveys have shown soil erosion is typically reduced by $60-80 \%$ (Hicks 1989, 1991; Hicks et al. 1993). Tree spacings achieving this level of protection vary depending on the type and extent of soil erosion. On severely eroding areas, poplars are generally less than $12 \mathrm{~m}$ apart. However, tree spacings increase up to $20 \mathrm{~m}$ on more stable areas of hillslopes (Hicks et al. 1993; Thompson \& Luckman 1993; Wilkinson 1999).

At Muriwai, near Gisborne, Gilchrist et al. (1993) found 16 year-old poplars at least $20 \mathrm{~m}$ apart had little effect on annual pasture DM production. However, in the Pohangina Valley, near Palmerston North, GuevaraEscobar et al. (1997) measured a 40\% annual reduction directly under large/mature unpruned poplars spaced 16 $\mathrm{m}$ apart. This suggests that farmers require more information on the best way to manage soil conservation stands of poplar to minimise any negative impact that these trees may have on understorey pasture DM production as they mature and their canopies develop. Such information would also prove invaluable for future cost/benefit analyses (Parminter et al. 2001; Thorrold et al. 1997).

Understorey pasture DM production is strongly related to overstorey canopy closure (Knowles et al. 1999) and, unlike tree spacing, this index also accounts for both the arrangement and size of the trees. Hence, the objective of this paper was to develop a relationship between poplar canopy closure and understorey pasture DM production, which can be used by farmers to optimise the spacing of poplar-stands for multiple objectives, such as soil conservation and pasture grazing.

\section{Materials and Methods \\ Sites}

The study was conducted on three commercial sheep and beef hill farms: one was located at Kiwitea in Manawatu; two were adjacent properties at Hautope in Central Hawke's Bay. The two regions were selected for their contrasting summer-wet and -dry climates (Burgess 1983; Thompson 1987). Each farm had a large number of mature poplar stands ( $>25$ years old) planted at spacings $(5-32 \mathrm{~m})$ covering those typically used for soil conservation and agroforestry. The trees were untended Populus x euramericana (Dode) Guinier black hybrid clones, consisting mainly of older Italian bred selections 
Table 1 Measurement sites at each sheep and beef hill farm.

\begin{tabular}{lccc}
\hline Farm & \multicolumn{2}{c}{$\begin{array}{c}\text { Number of measurement sites } \\
\text { Amongst trees }\end{array}$} & \multicolumn{2}{c}{$\begin{array}{c}\text { Tree spacings } \\
(\mathrm{m})\end{array}$} \\
\hline Kiwitea & Open pasture & 11 & $11-32$ \\
Hautope 1 & 3 & 10 & $5-18$ \\
Hautope 2 & 2 & 4 & $6-18$ \\
\hline
\end{tabular}

such as I78, I214, and I488 (Fung pers. comm. 2001). Average tree diameter at breast height (DBH; $1.4 \mathrm{~m}$ on the upslope side of the trunk) was $0.74 \mathrm{~m}, 0.43 \mathrm{~m}$, and $0.23 \mathrm{~m} \pm 0.02 \mathrm{~m}$ (mean \pm standard error of mean) at Kiwitea, Hautope 1, and Hautope 2, respectively. Topography varied between hill and steepland $\left(15-36^{\circ}\right)$. Soils at Kiwitea were Raumai hill soil on easier slopes and hilltops and Pohangina steepland soil on steep and broken areas (Rijkse 1977; Suckling 1975). Hautope 1 and 2 had Hatuma-Raukawa soils (Pohlen 1971). All three farms were annually topdressed with superphosphate fertiliser at $200-300 \mathrm{~kg} / \mathrm{ha}$.

Grasses dominated the pastures. Kiwitea and Hautope 1 pastures in spring and summer contained $40-50 \%$ high fertility responsive (HFR) grasses, consisting mainly of
Lolium perenne and Poa spp. In contrast, at Hautope 2 HFR grasses made up only $5 \%$ of the total sward biomass and were almost entirely Lolium perenne. Other grasses present were Agrostis capillaris, Anthoxanthum odoratum, and Cynosurus cristatus. At Kiwitea in both open (without trees) and tree environments the pasture had about $8 \%$ legume. A similar percentage also occurred in the open at Hautope 1. However, amongst the trees, understorey pastures contained less than $2 \%$ legume. At Hautope 2 the legume content was low at around $1 \%$ of total sward biomass in all environments (unpublished data).

Measurement sites at each farm were selected to span a wide range of poplar canopy closures (including open pasture control areas) (Table 1). Each site with trees

Figure 1 A range of poplar canopy closures taken mid-way between the trees.

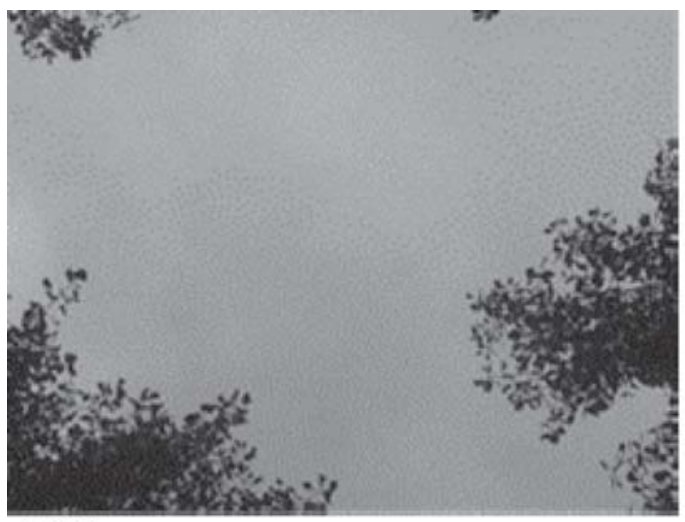

$20 \%$

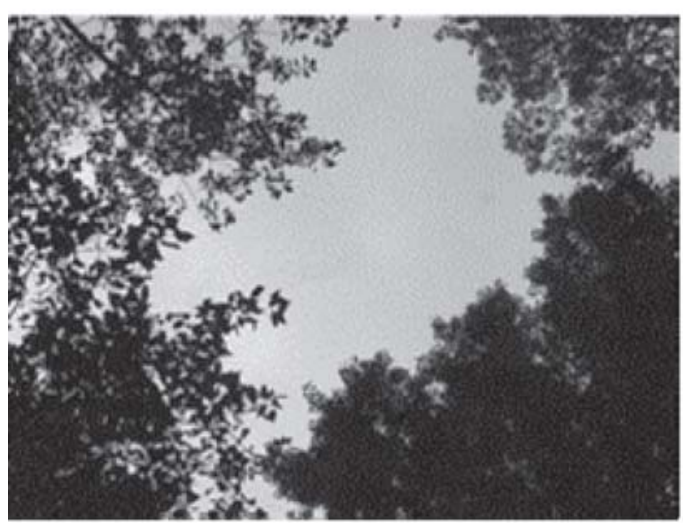

$60 \%$

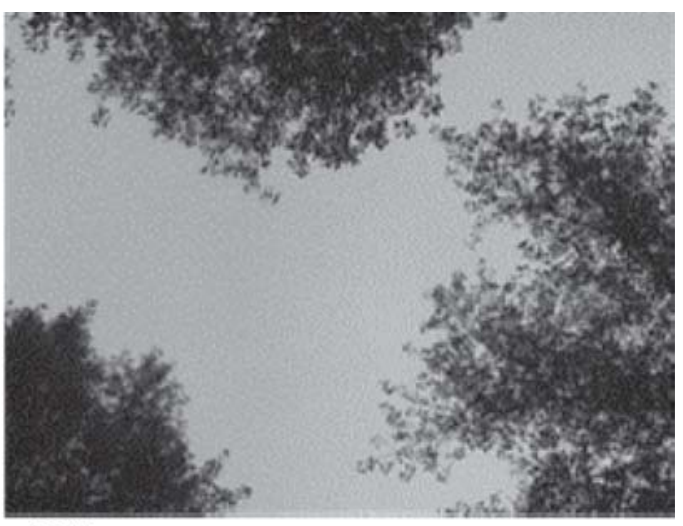

$40 \%$

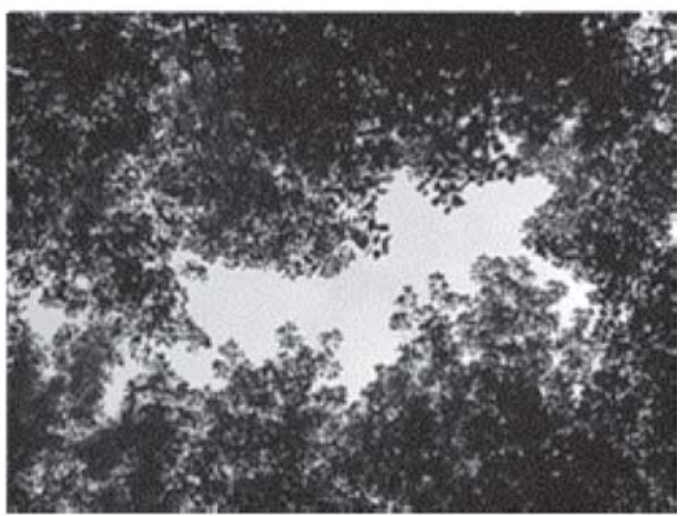

$80 \%$ 
consisted of four nuclei trees planted in a square pattern surrounded with buffer trees of similar size and spacing. Open pasture controls were located at least $50 \mathrm{~m}$ away from the trees. All of the selected sites at Kiwitea, Hautope 1 , and Hautope 2 were on north, southeast, and northwestfacing aspects, respectively. Measurement sites were regularly grazed as part of normal farm management.

\section{Canopy closure}

Seventeen colour images of the overstorey canopy vertically above each selected measurement site were taken with a Sony MVC-FD7 digital camera, using its standard lens (producing rectangular non-equidistant images). Wherever possible, images were captured under calm and completely overcast sky conditions to maximise image contrast and minimise interference by direct sunlight (e.g. sun-spots). Sampling dates at Kiwitea and Hautope $(1 \& 2)$ were 25/01/99 and 13/02/01, respectively. For each measurement site, the digital images were taken using a systematic sampling design (Knowles et al. 1999). This design involved taking a digital image at the centre of a site and then at distances $6 \mathrm{~m}$ and $12 \mathrm{~m}$ outwards from this point along the eight major compass directions (making a star shaped pattern). Figure 1 gives examples of different levels of canopy closure taken midway between the trees.

Digital image analysis was based on the method given by Guevara-Escobar (1999). Corel Photo-paint ${ }^{\circledR}$ (version 9.0 for Windows ${ }^{\circledR}$, Corel Corp. 1999) was used to identify and separate tree and sky areas of an image based on their respective colours. Using the same computer program, these two areas were then converted to purely black and white colours, respectively. The number of black pixels in the simplified image were counted using SigmaScan ${ }^{\circledR}$ Pro (version 4.0 for Windows ${ }^{\circledR}$, SPSS Inc. 1998) and divided by the total number of pixels making up the image ( $640 \times 480$ pixels) to give the canopy closure ratio. For each site, canopy closure was based on the mean of the 17 digital images.

\section{Pasture DM production}

Pasture DM production was measured for 2 years at Kiwitea (October 1998 - September 2000) and 1 year at Hautope 1 and 2 (May 1999 - April 2000). Sampling at each of the selected sites was restricted to slopes of 13$25^{\circ}$ and, amongst the poplars, was limited to anywhere directly beneath the shaded side of one of the nuclei trees and in the gap mid-way between the same trees. Pasture DM production was measured under $0.7 \mathrm{~m}^{2}$ grazing exclusion cages using the double-trim technique (Radcliffe 1974). Pasture cuts were at monthly intervals, except during some winter and late summer/autumn months because of slow pasture growth. Consequently, 6-7 cuts were taken each year.

\section{Statistics}

The relationship between poplar canopy closure and annual pasture DM production was determined by regression analysis, using the REG and NLIN procedures of $\mathrm{SAS}^{\circledR}$ (version 8.02 for Windows ${ }^{\circledR}$, SAS Institute, Inc. 1999).

\section{Results and Discussion}

Annual pasture DM production under the poplars decreased at a slightly diminishing rate with increasing canopy closure (Fig. 2). The exponential decay curve fitted was highly significant $(\mathrm{P}<0.0001)$ and accounted for $77 \%$ of the measured variation in pasture $\mathrm{DM}$ production. Further sampling under canopy closures of $10-40 \%$ would clearly improve the robustness of the developed model, but were unavailable at the selected farm sites. Underneath $25 \%, 50 \%$, and $75 \%$ poplar canopy closure, annual pasture DM production was predicted to be $77 \%, 60 \%$, and $48 \%$ of open pasture on relatively uneroded ground, respectively (Fig. 2). This supports Guevara-Escobar et al's (1997) finding that understorey pastures can be markedly suppressed under high poplar canopy closure. Similarly, in Ireland, Crowe (1993) found pasture DM production under mature 35year old $P$. serotina trees planted at close spacings $(6 \mathrm{~m})$ was suppressed by about $50 \%$.

However, the loss of pasture production beneath poplars needs to be balanced against the potential losses due to soil erosion, which can be greater and more permanent. Pastures on fresh soil and earth slip scars are partially to completely destroyed (Hawley 1987; Hicks 1992). Studies on Wairarapa, Wairoa, and Taranaki hill country farms have shown that recovery of these scars takes 20 to 40 years to reach levels equivalent to $70-80 \%$ of the production of neighbouring uneroded sites, with little further recovery thereafter (DeRose et al. 1995; Douglas et al. 1986; Lambert et al. 1984). Apart from tension cracks, the ground surface on earthflows remains intact. However, disruption to the underlying soil can severely reduce the productive capacity of the site. At Waimata, Miller et al. (1996) found pasture DM production on new and old (still active) earthflows was $23 \%$ and $60 \%$, respectively, of adjacent uneroded sites. The rate of pasture recovery depends on factors such as the climate, soil depth, underlying rock type, frequency of erosion events, and post management of the eroded site (DeRose et al. 1995; Quilter et al. 1993). Pasture production lost from erosion is both less predictable and less sustainable than a managed decrease in pasture production resulting from the planting of poplars.

These results can be incorporated into improved management of pasture-poplar systems. Farmers and regional council officers could use canopy photographs as in Figure 1, or other measures of canopy closure, to 
Figure 2 Relationship between annual pasture DM production and poplar canopy closure. Standard errors for

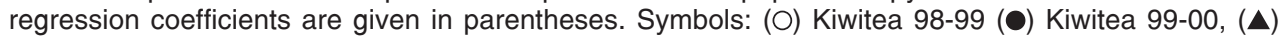
Hautope 1, ( $\square$ ) Hautope 2. Solid line - mean predicted response. Abbreviations: $r^{2}$, coefficient of determination (estimated for non-linear model); RMSE, standard error of prediction

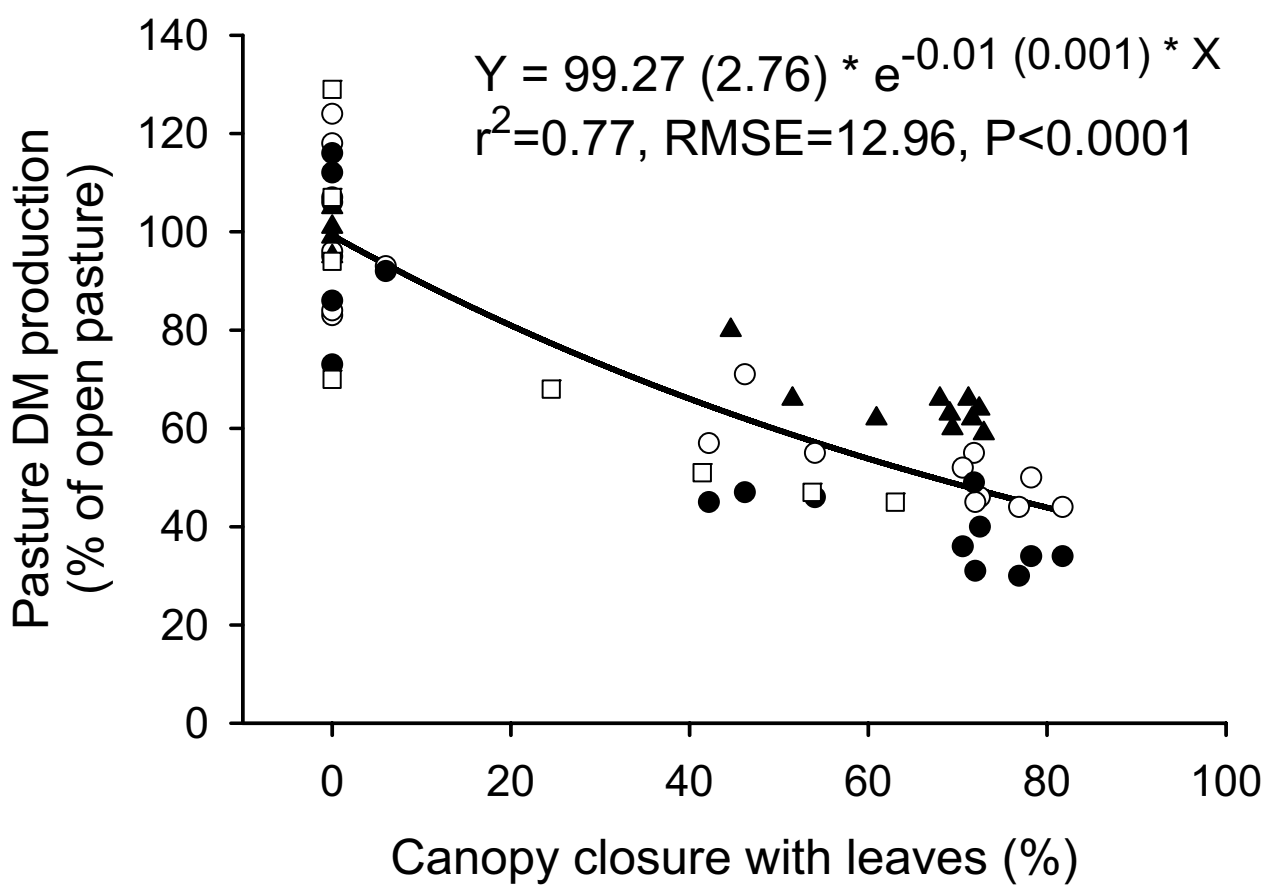

determine the degree of silviculture required to maintain pasture production at $65-75 \%$ of adjacent uneroded open pasture. In the past insufficient control of poplar canopy closure has led to poor pasture production and farmer disenchantment with some plantings of widely spaced conservation trees. Use of the canopy closure relationship with pasture DM production presented will encourage maintaining canopy closure at less than $50 \%$ as widely spaced poplars mature, allowing the pasture production under the trees to stabilise. Pruning, pollarding, or thinning poplars in summer combines good silvicultural practice with a time of the year when the poplar leaves and thin branches provide better quality forage than dry summer pasture (Kemp et al. 2001). However, reducing the size of the overstorey canopy will have consequential effects on soil-water relations and tree-root development, which in turn will affect the trees protective function.

\section{Conclusion}

Soil conservation stands of poplar on hill pastures require silvicultural management to control the degree of canopy closure formed as the trees mature. At high canopy closures understorey pasture DM production is markedly reduced, although it still may be greater than if the hill slope is left to erode. Limiting canopy closure to less than $50 \%$ will ensure annual pasture DM production is maintained at greater than $65-75 \%$ of that of open pastures on adjacent uneroded ground. Canopy photographs provide a simple scale to gauge the level of canopy closure.

\section{ACKNOWLEDGEMENTS}

We thank Allister Clark and later Darrell Shellard (Kiwitea), John Dunderdale and Martin Meredith (Hautope) for use of their farms. Federated Farmers of New Zealand Inc. (Manawatu/Rangitikei), Hawke's Bay Regional Council (Neil Faulknor), and New Zealand Landcare Trust (Ewan McGregor) helped find the farm sites. Lindsay Fung (HortResearch) identified the poplar species and hybrids. AgResearch and the Poplar and Willow Research Collective provided funding.

\section{REFERENCES}

Burgess, S.M. 1983. The climate and weather of Manawatu and Horowhenua. New Zealand Meterological Service, Wellington, New Zealand. 47 pp.

Crowe, S.R. 1993. The response of Lolium perenne and Holcus lanatus to shading in relation to a silvopastoral agroforestry system. PhD thesis. Queen's University of Belfast, Ireland.

DeRose, R.C.; Trustrum, N.A.; Thomson, N.A.; Roberts, A.H.C. 1995. Effect of landslide erosion on Taranaki hill pasture production and composition. New 
Zealand Journal of Agricultural Research 38: 457471.

Douglas, G.B.; Trustrum, N.A.; Brown, I.C. 1986. Effect of soil slip erosion on Wairoa hill pasture production and composition. New Zealand Journal of Agricultural Research 29: 183-192.

Gilchrist, A.N.; deZ Hall, J.R.; Foote, A.G.; Bulloch, B.T. 1993. Pasture growth around broad-leaved trees planted for grassland stability. pp. 2062-2063. In: Proceedings of the XVII International Grassland Congress.

Gregory, N.G. 1995. The role of shelterbelts in protecting livestock: A review. New Zealand Journal of Agricultural Research 38: 423-450.

Guevara-Escobar, A.; Kemp, P.D.; Hodgson, J.; Mackay, A.D.; Edwards, W.R.N. 1997. Case study of a mature Populus deltoides-pasture system in a hill environment. Proceedings of the New Zealand Grassland Association 59: 179-185.

Guevara-Escobar, A. 1999. Aspects of a poplar-pasture system related to pasture production in New Zealand. $\mathrm{PhD}$ thesis. Massey University, New Zealand.

Hathaway, R.L. 1986. Plant materials for slope stabilisation. pp 39-47. In: Plant materials handbook for soil conservation volume 1: Principles and practices. Eds. Van Kraayenoord, C.W.S.; Hathaway, R.L. Water and Soil Miscellaneous Publication No. 93. National Water and Soil Conservation Authority, Wellington, New Zealand.

Hawley, J. 1987. Soil conservation - should the user pay? Soil and Water: 4-7.

Hicks, D.L. 1989. Soil conservation in the Waihora catchment, East Coast. pp 47-56. In: Proceedings New Zealand Association of Soil and Water Conservation Conference, Nelson, New Zealand.

Hicks, D.L. 1991. Effect of soil conservation tree plantings on damage sustained by the Whareama catchment during the storm of 8-11 April 1991. Department of Scientific and Industrial Research, Contract Report 91/106.

Hicks, D.L. 1992. Impact of soil conservation on stormdamaged hill grazing lands in New Zealand. Australian Journal of Soil and Water Conservation 5: 34-40.

Hicks, D.L.; Fletcher, J.R.; Eyles, G.O.; McPhail, C.R.; Watson, M. 1993. Erosion of hill country in the Manawatu-Wanganui Region 1992: Impacts and options for sustainable land use. Landcare Research New Zealand Ltd., Contract Report LC 9394/51. 90 pp.

Kemp, P.D.; Mackay, A.D.; Matheson, L.A.; Timmins, M.E. 2001. The forage value of poplars and willows. Proceedings of the New Zealand Grassland Association 63: 115-119.

Knowles, R.L.; Horvath, G.C.; Carter, M.A.; Hawke,
M.F. 1999. Developing a canopy closure model to predict overstorey/understorey relationships in Pinus radiata silvopastoral systems. Agroforestry Systems 43: 109-119.

Lambert, M.G.; Trustrum, N.A.; Costall, D.A. 1984. Effect of soil slip erosion on seasonally dry Wairarapa hill pastures. New Zealand Journal of Agricultural Research 27: 57-64.

McGregor, E.; Mackay, A.D.; Dodd, M.; Kemp, P.D. 1999. Silvopastoralism using tended poplars on New Zealand hill country: The opportunities. Proceedings of the New Zealand Grassland Association 61: 8589.

McKee, J. G. 1973. Use of trees. pp 31-38. In: Prevention and control of mass movement and gully erosion. Ministry of Works and Development, Wellington, New Zealand.

Miller, D.E.K.; Gilchrist, A.N.; Hicks, D.L. 1996. The role of broad-leaved trees in slope stabilisation in New Zealand pastoral farming. pp 96-104. In: Mountains of East Asia and the Pacific. Eds. Ralston, M.M.; Hughey, K.F.D.; O'Connor, K.F. New Zealand Centre for Mountain Studies, Lincoln University, Canterbury, New Zealand.

NZFRI 1995. Poplar. pp. 47-51. In: Small Forest Management 1: Special purpose timber species. Ministry of Forestry and New Zealand Forest Research Institute Ltd, Wellington, New Zealand.

Parminter, I.; Dodd, M.B.; Mackay, A.D. 2001. Economic analysis of poplar planting on steep hill country. Proceedings of the New Zealand Grassland Association 63: 127-130.

Pohlen, I.J. 1971. Soils of Hawke's Bay region New Zealand. New Zealand Department of Scientific and Industrial Research, Wellington, New Zealand. 57 pp.

Quilter, S.J.; Korte, C.J.; Smith, D.R. 1993. Low cost revegetation of slips near Gisborne. Proceedings of the New Zealand Grassland Association 55: 187-191.

Radcliffe, J.E. 1974. Seasonal distribution of pasture production in New Zealand 1. Methods of measurement. New Zealand Journal of Experimental Agriculture 2: 337-340.

Rijkse, W.C. 1977. Soils of Pohangina County North Island, New Zealand. New Zealand Department of Scientific and Industrial Research, Wellington, New Zealand. $70 \mathrm{pp}$.

Suckling, F.E.T. 1975. Pasture management trials on unploughable hill country at Te Awa. 3. Results for 1959-69. New Zealand Journal of Experimental Agriculture 3: 351-436.

Thorrold, B.S.; Knowles, R.L.; Nicholas, I.D.; Power, I.L.; Carter, J.L. 1997. Evaluation of agroforestry options for three tree species. Proceedings of the New Zealand Grassland Association 59: 187-190. 
Thompson, C.S. 1987. The climate and weather of Hawke's Bay. New Zealand Meterological Service, Wellington, New Zealand. 46 pp.

Thompson, R.C.; Luckman, P.G. 1993. Performance of biological erosion control in New Zealand soft rock hill terrain. Agroforestry Systems 21: 191-211.

Wall, A.J.; Mackay, A.D.; Kemp, P.D.; Gillingham, A.G.;
Edwards, W.R.N. 1997. The impact of widely spaced soil conservation trees on hill pastoral systems. Proceedings of the New Zealand Grassland Association 59: 171-177.

Wilkinson, A.G. 1999. Poplars and willows for soil erosion control in New Zealand. Biomass and Bioenergy 16: 263-274. 